\title{
Impact of Human Disturbance on Fiddler Crab (Uca tangeri) Burrow Morphology, Distribution and Chemistry at Eagle Island, Niger Delta, Nigeria
}

\author{
Aroloye 0. Numbere \\ Department of Animal and Environmental Biology, University of Port Harcourt, Choba, Nigeria \\ Email: aroloyen@yahoo.com
}

How to cite this paper: Numbere, A.O. (2020) Impact of Human Disturbance on Fiddler Crab (Uca tangeri) Burrow Morphology, Distribution and Chemistry at Eagle Island, Niger Delta, Nigeria. Open Journal of Marine Science, 10, 191-202. https://doi.org/10.4236/ojms.2020.104015

Received: July 8, 2020

Accepted: August 23, 2020

Published: August 26, 2020

Copyright () 2020 by author(s) and Scientific Research Publishing Inc. This work is licensed under the Creative Commons Attribution International License (CC BY 4.0).

http://creativecommons.org/licenses/by/4.0/

\section{(c) (i) Open Access}

\begin{abstract}
Fiddler crabs are described as ecosystem engineers because of their burrow constructing ability. It was hypothesized that human activity will impact crab burrows. The study area was delineated into lowly, medium and highly impacted plots. Crab holes were randomly counted and their width, length and surface area estimated. Burrow soils were collected and analyzed for Cadmium $(\mathrm{Cd})$, Lead $(\mathrm{Pb})$ and Zinc $(\mathrm{Zn})$ using spectrophotometric method (HACH DR 890 colorimeter). The result indicates that burrow width was significantly different between impacted plots $(\mathrm{P}<0.05)$. Lowly impacted plot had the largest width while highly impacted plot had the smallest width. In contrast, there was no significant difference in burrow length $(\mathrm{P}>0.05)$, but highly impacted plot has the longest length while lowly impacted plot has the shortest length. Again, the surface area of crab burrow varies significantly ( $P$ $<0.05)$, and lowly impacted plot had the largest area $\left(507.95 \pm 61.84 \mathrm{~cm}^{2}\right)$ followed by medium $\left(390.30 \pm 57.65 \mathrm{~cm}^{2}\right)$ and high $\left(265.16 \pm 30.85 \mathrm{~cm}^{2}\right) \mathrm{im}-$ pacted plots. Similarly, lowly impacted area has more number of burrows ( $n$ $=55)$ followed by medium $(n=30)$ and highly $(n=23)$ impacted plots. Highly impacted plot had the highest $\mathrm{Cd}$ and $\mathrm{Pb}$ concentration whereas lowly impacted plot had the highest $\mathrm{Zn}$ concentration. This implies that burrow morphology and chemistry exemplify the level of anthropogenic impact.
\end{abstract}

\section{Keywords}

Burrow, Human Disturbance, Heavy Metals, Mangroves, Fiddler Crab, Sand Fill

\section{Introduction}

The exploding population of humans in overcrowded cities is increasingly 
putting pressure on coastal areas of the Niger Delta with the conversion of many forests into places of human habitation and construction (e.g. houses, roads and industrial estates). These construction activities had changed the configuration of the coastal system, which has a lot of organisms such as the dexterous fiddler crabs (Uca tangeri) that live in burrows along the shore. They have a color combination of orange, black and white, and their males have giant-sized right pincers, which they wave at the females during mating, and use to defend their territory against predators. Furthermore, it has been observed during field work that the large pincer of the male crab is waved when high tide is being expected. This is because there is a local belief that the waving of the right pincer signals the approaching of tidal current. Fiddler crabs perform other vital functions within the coastal environment, for instance they help recycle nutrient and energy in mangrove forest [1] [2]. By their filter feeding habit, they also consume microphytobenthos and plant litter from substrates [3]. Crabs are omnivorous and feed on any material such as fish, brine shrimp and sea urchin eggs [4] [5].

The fiddler crabs of the super family Ocypodoidea are good ecosystem engineers because of their exceptional burrow constructing skills [6], which affects the soil chemistry. Three basic types of burrow constructed by the fiddler crabs [7] include: 1) chimneys which are a sedimentary structure similar to a wall surrounding the entire edge of the burrow; 2) opening hoods which are a sedimentary structure of semicircular shape, forming a covering that protects part of the burrow opening and 3) pillars which are sedimentary structures piled next to the burrow opening [8] [9]. Fiddler crabs build deep or shallow burrows and live inside or stay outside the holes [10]. During low tides they emerge from their holes to scout for food items ranging from microalgae to plant litter [11]. They also clean the soil surface by picking up litter during low tides and transport seeds from one part of the forest to another leading to formation of zonation patterns in mangrove forests [12].

Crabs influence sediment formation through their bioturbation activities [9], which include re-design of burrows, carving of ventilation outlets, creation of flow channels and construction of protective walls against external intruders [9]. Furthermore, their burrowing also impacts soil chemistry by changing the $\mathrm{pH}$, oxygen, heavy metal, nutrient and dinitrogen oxide content of the soil [13]. That is why Hanim et al. [14] described them as keystone species because of their high impact on forest ecosystem. However, the impact of human activities will limit their ability to construct burrows and render other ecosystem services.

This study therefore, hypothesized that burrow morphology (i.e. length, width and surface area), distribution and chemistry can provide evidence of human impact on coastal environment. This is because the study area serves as a pedestrian route for those going to take commercial boats, which conveys people across the river. Fiddler crabs were used for this study because they make $90 \%$ of the crab population in this study area. The goal of this study therefore, was to compare the burrow width, length and surface area, number of burrows and chemistry of soil in high, medium and low impacted plots. The objective of the 
study therefore are: 1) to determine the burrow width, length and surface area in low, medium and high impact plots, 2) to determine the total number of burrows in low, medium and high impact plots and 3) to compare the burrow chemistry between low, medium and high impact plots.

\section{Materials and Methods}

\subsection{Description of Study Area}

The study was conducted in a mangrove patch that was formerly used as sand dump [15] directly behind the Rivers State University at Eagle Island, Niger Delta (N $4^{\circ} 47.317^{\prime}$, E $\left.6^{\circ} 58.593^{\prime}\right)$. The area is connected to a river, and can only be accessed by foot for those who want to walk the distance to board a boat. The area has high rainfall which occurs from January to December each year. The site is a mixture of sandy and clayey soil, which is white to dark brown in color. The lowly impacted area (sea shore) has white soil, the medium impacted area (sand filled) has light brown soil and the highly impacted area (foot path) has dark brown soil. The soil texture is loose to muddy. Field observations indicate that sandy soil has low plasticity, which means it cannot be molded whereas the foot path soil can be molded into shapes when wet but difficult to mold when dry. The $\mathrm{pH}$ of the soil was measured with a Kelway soil tester (Japan) in situ and ranged between $6-7$. The foot path and the seashore areas of the study site are often covered by water during high tide while the sand fill remain above water during high tide. During low tides the crabs emerge from their holes to forage while during high tides they hide in their holes [16].

\subsection{Plot Delineation}

The study area is delineated into three plots i.e. habitat types namely: sand fill (i.e. medium impact), foot path (high impact) and seashore (low impact) plots (Figure 1(a)). In each plot several crab burrows were randomly identified and the width (diameter) and length (burrow depth below sediment surface) measured with a flexible elephant grass stem that was placed across and also pushed down to the end of the burrow, after which the stick was placed on a meter rule to get the size. A slightly hard, but flexible elephant grass stem (Pennisetum purpereum) was used because it bends easily and meanders through the burrow without breaking. The stem was pushed hard through the hole until it get to its final stop, which marks the end of the burrow. This is verified by several trial to ensure that the stem had reached the end of the hole. The number of burrows in each plot were also enumerated (Figure 1(b)). The distance of each plot to the adjoining river and from the disturbed area (foot path) was also measured with a measuring tape.

Since a burrow is assumed to be a simple cylinder (Figure 1(c)), surface area of a cylinder was calculated as shown in Equation (1), where $r$ is radius and $h$ is burrow depth.

$$
A=2 \pi r h+2 \pi r^{2}
$$




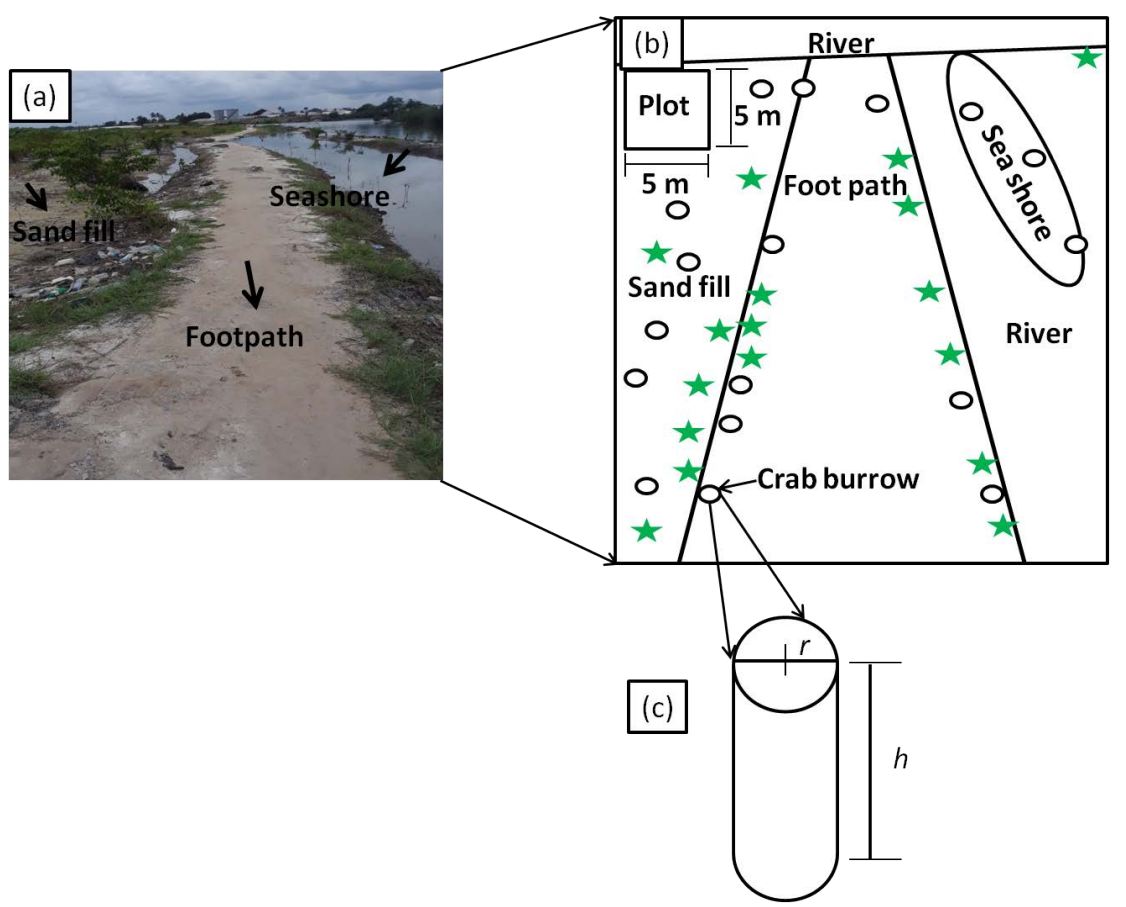

Figure 1. (a) and (b) Experimental design showing crab burrows at three different plots: sand fill (medium impact), foot path (high impact) and sea shore (low impact) at Eagle Island, Niger Delta, Nigeria, (c) burrow forms a simple cylinder.

\subsection{Sample Collection}

Burrow soils (i.e. soils dug out by the crabs) were scooped from the soil surface randomly from ten points in each plot $(n=30)$ and placed in cellophane bag and sent to the laboratory for metal analysis for Cadmium, Lead and Zinc.

\subsection{Strength of Soil}

The strength of the soil from the different habitat types was tested with a pocket penetrometer to determine their compaction. Twenty different points on each habitat type were tested to derive an average in tones $/ \mathrm{cm}$.

\subsection{Laboratory Analysis}

\subsubsection{Procedure of Total Hydrocarbon Content Analysis}

It involved the use of spectrophotometric method using the calorimeter (i.e. HACH DR 890). The samples were crushed and $2 \mathrm{~g}$ of the crushed sample was weighed into a glass beaker and $20 \mathrm{ml}$ of hexane was added, and with the aid of a glass rod, the mixture was homogenized by stirring. Afterwards, the sample was filtered in a glass funnel packed with cotton wool, silica gel and anhydrous sodium sulphate. After this, $10 \mathrm{ml}$ of the filtered organic extract was transferred into a $10 \mathrm{ml}$ sample curvet and inserted into the calorimeter. The detection limit for THC is $0.01 \mathrm{mg} / \mathrm{l}[17]$.

\subsubsection{Heavy Metal Analysis}

Heavy metal extraction followed the example of Aigberua and Tarawou [18]. 
Aliquots of $0.25 \mathrm{~g}$ of air dried sediment samples were weighed into a Teflon inset of a microwave digestion vessel and $2 \mathrm{ml}$ concentrated (90\%) nitric acid (Sigma-Aldrich, Dorset, UK) were added. The metals were extracted using a microwave accelerated reaction system (MARS Xpress, CEM Corporation, Matthews, North Carolina) at $1500 \mathrm{~W}$ power (100\%), ramped to $175^{\circ} \mathrm{C}$ in $5.5 \mathrm{~min}$, held for $4.5 \mathrm{~min}$, and allowed to cool down for $1 \mathrm{~h}$. The cool digest solution was filtered through the Whatman 42 filter paper and made up to $100 \mathrm{ml}$ in a volumetric flask by adding de-ionized water. The detection limit for the three metals analyzed in $\mathrm{mg} / \mathrm{l}$ i.e. Zinc, Cadmium and Lead is 0.001, 0.001 and 0.002 respectively [19].

\subsection{Statistical Analysis}

An analysis of variance (ANOVA) was conducted to determine whether there was a significant difference in the area (width and length) of burrow holes in each plot. Similarly, and ANOVA was done to determine whether there is any significant difference in heavy metal concentration in the different plots. Similarly, ANOVA was used to test the significance difference of surface area of burrow in different impacted plots. The data was first log transformed to ensure that they were normal and the variances were equal [20]. Bar graphs were then used to illustrate heavy metal concentration and burrow area in different pots [21]. All analysis was performed in $R$ statistical environment [22].

\section{Results}

\subsection{Morphology of Burrows}

The ANOVA result indicates that there is significant difference in width of burrow hole in different impacted plots $\left(\mathrm{F}_{2,149}=6.51, \mathrm{P}=0.002\right)$. Lowly (seashore) impacted plot had the largest burrow width followed by medium (sand fill) and highly (foot path) impacted plots. In contrast, there was no significant difference in length of burrow in all impacted plots $\left(\mathrm{F}_{2,149}=1.07, \mathrm{P}=0.35\right)$. For length, the size is opposite to that of width, which means the high impact plot had the longest burrow length followed by medium and low impact plots. Furthermore, there was a significant difference in burrow area in different impact plots $\left(\mathrm{F}_{2,149}=4.10, \mathrm{P}=0.02\right)$, and the order of the size of burrow area is low $>$ medium $>$ high.

\subsection{Surface Area of Burrows in Different Impacted Areas}

The ANOVA result reveals that there is significant difference in surface area of burrows in different impacted plots $\left(F_{2,149}=6.23, \mathrm{P}=0.003\right.$, Figure 2$)$. Burrow in lowly impacted area has the largest surface area $\left(507.95 \pm 61.84 \mathrm{~cm}^{2}\right)$, followed by medium $\left(390.30 \pm 57.65 \mathrm{~cm}^{2}\right)$ and highly $\left(265.16 \pm 30.85 \mathrm{~cm}^{2}\right)$ impacted plots.

\subsection{Burrow Numbers}

The result indicates that the number of burrows counted within the different habitat types was highest in seashore followed by sand fill and foot path (Table 1). 
Table 1. Number of burrows and the soil compaction of different habitat types at Eagle Island, Niger Delta Nigeria. The distances from the river and foot path were measured to determine if they influenced the number of burrows constructed by crabs.

\begin{tabular}{ccccc}
\hline Habitat types & $\begin{array}{c}\text { Number of } \\
\text { burrows }\end{array}$ & $\begin{array}{c}\text { Distance from river } \\
(\mathrm{m})\end{array}$ & $\begin{array}{c}\text { Distance from foot } \\
\text { path }(\mathrm{m})\end{array}$ & $\begin{array}{c}\text { Soil compaction } \\
\text { (tones/cm } \pm \text { SE) }\end{array}$ \\
\hline Seashore & 55 & 0.3 & 3.2 & $0.96 \pm 0.13$ \\
Sand fill & 30 & 2.6 & 0 & $0.26 \pm 0.02$ \\
Footpath & 23 & 7.0 & 1.2 & $2.04 \pm 0.15$
\end{tabular}

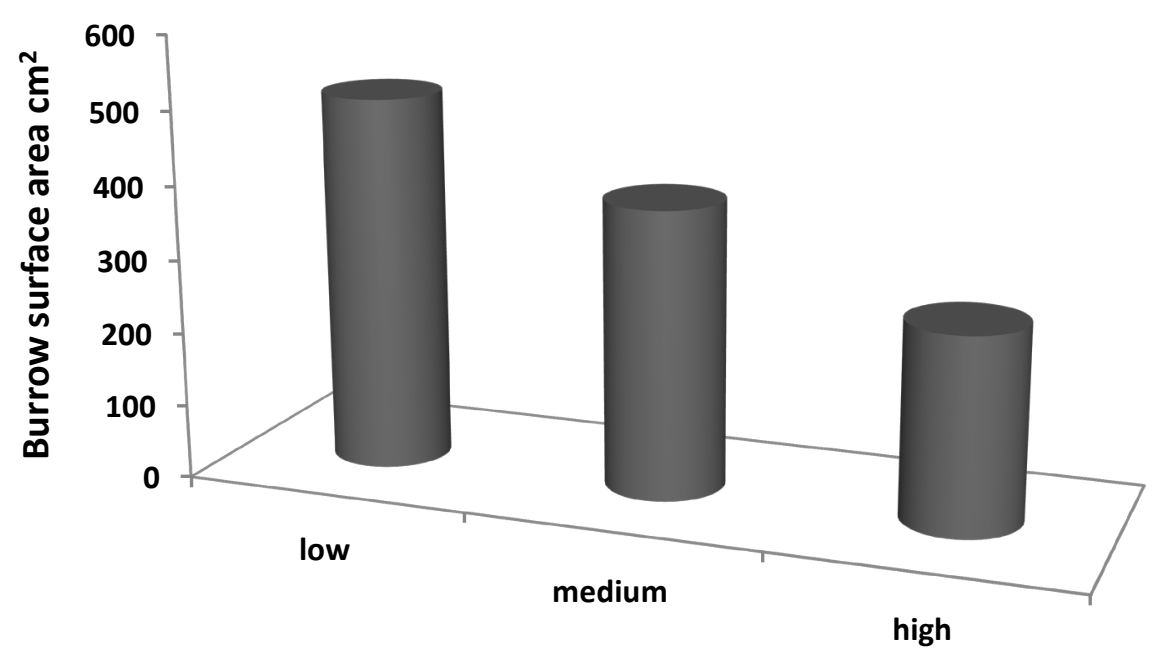

Impact types

Figure 2. Graph of burrow surface area versus impact types. Low impact type refers to seashore, medium impact type refers to sand fill and high impact type refers to footpath.

\subsection{Chemical Concentration of Burrow Soil}

The ANOVA results (Table 2, Figure 3) indicates that there is no significant difference in heavy metal concentration between burrow soils $\left(\mathrm{F}_{2,15}=3.30, \mathrm{P}=\right.$ 0.07), although, in the overall highly impacted plot had the highest concentration of heavy metals followed by lowly and medium impacted plots. The order of metal concentration in each plot is high $>$ low $>$ medium. Highest Cadmium concentration was recorded in highly impacted plot $(0.45 \pm 0.01 \mathrm{mg} / \mathrm{l})$ followed by lowly and $(0.41 \pm 0.01 \mathrm{mg} / \mathrm{l})$ and medium $(0.002 \pm 0.001 \mathrm{mg} / \mathrm{l})$ impacted plots. Similarly, highest Lead was recorded in highly impacted plot $(28.33 \pm 0.88 \mathrm{mg} / \mathrm{l})$ followed by lowly $(8.41 \pm 0.12 \mathrm{mg} / \mathrm{l})$ and medium $(0.13 \pm 0.01 \mathrm{mg} / \mathrm{l})$ impacted plots. However, highest Zinc concentration was recorded in lowly impacted plot $(10.71 \pm 0.40$ $\mathrm{mg} / \mathrm{l})$ followed by highly $(9.03 \pm 0.08 \mathrm{mg} / \mathrm{l})$ and medium $(2.44 \pm 0.07 \mathrm{mg} / \mathrm{l}) \mathrm{im}-$ pacted plots. The Tukey HSD test indicates that the most significant difference lies between medium and highly impacted plots $(\mathrm{P}<0.05)$ (Figure 3$)$.

In contrast, there was significant difference between heavy metals $\left(\mathrm{F}_{2,15}=3.56\right.$, $\mathrm{P}=0.04)$, The Tukey HSD test indicates that the most significant difference lies between lead and Cadmium $(\mathrm{P}<0.05)$ (Figure 3 ). 
Table 2. Mean heavy metal concentration in different plots at sand filled mangrove forest in Eagle Island, Niger Delta Nigeria. ANOVA was used to calculate the significant difference from the mean of ten soil collection points per plot (i.e. $n=30)$.

\begin{tabular}{ccccc}
\hline Plots & \multicolumn{3}{c}{ Metals $(\mathrm{mg} / \mathrm{kg}) \pm \mathrm{SE}^{*}$} & P-value \\
\hline & Cadmium & Lead & Zinc & \\
\hline Foot path (High) & $0.45 \pm 0.01$ & $28.33 \pm 0.88$ & $9.03 \pm 0.08$ & $>0.05$ \\
Sand fill (Medium) & $0.002 \pm 0.001$ & $0.13 \pm 0.01$ & $2.44 \pm 0.07$ & $>0.05$ \\
Seashore (Low) & $0.41 \pm 0.01$ & $8.41 \pm 0.12$ & $10.71 \pm 0.40$ & $>0.05$ \\
\hline
\end{tabular}

$*$ Standard error $(\mathrm{SE})=\frac{\sigma}{\sqrt{n}}$.

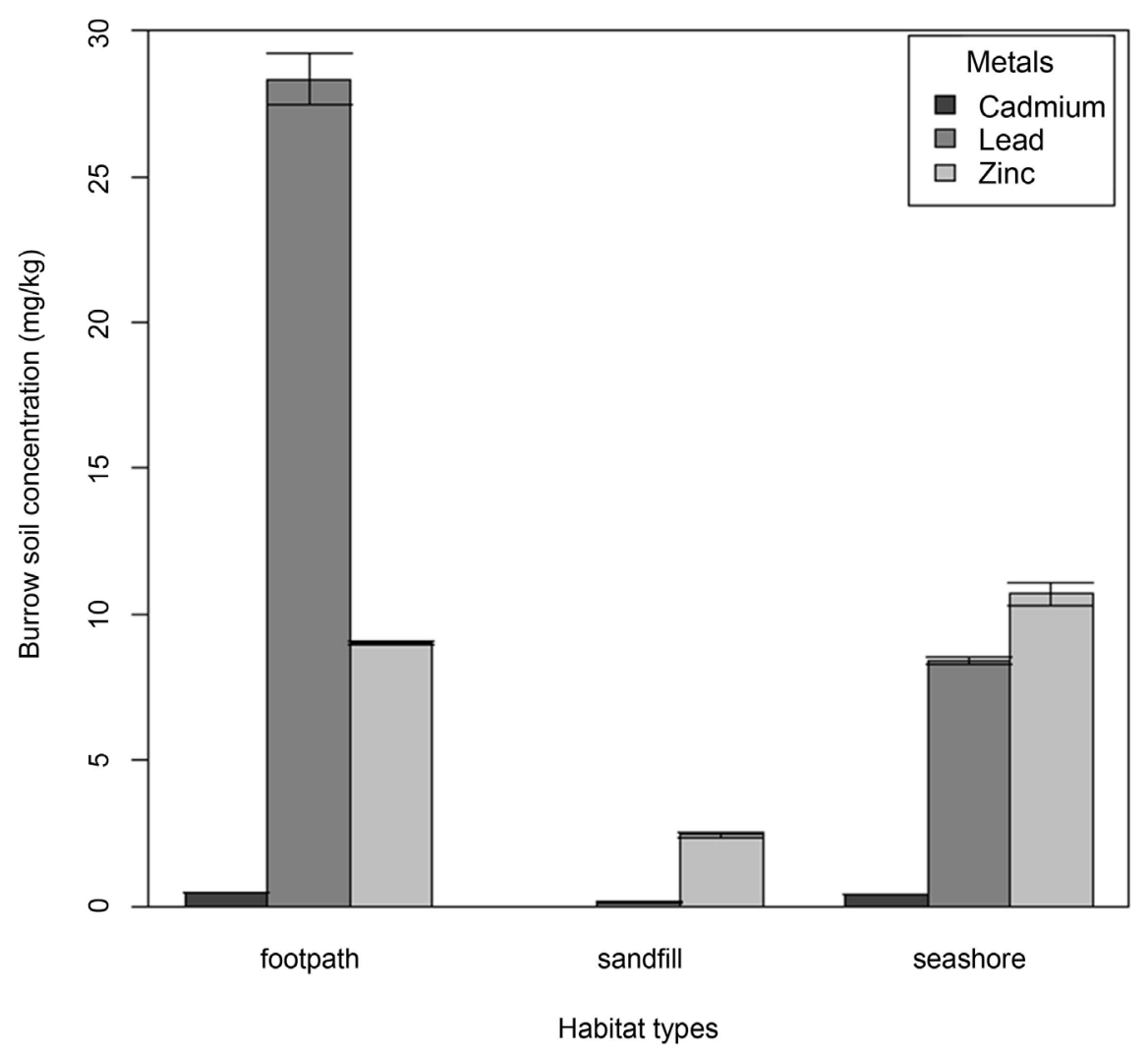

Figure 3. Graph of heavy metal concentration in different habitat types at Eagle Island, Niger Delta, Nigeria. Foot path is highly impacted plot, sand fill is medium impacted plot while seashore is lowly impacted plot.

\section{Discussion}

Crabs are good engineers because of the architectural prowess they exhibit in designing and building interconnecting burrows within the soil [23]. In this study crabs might have built wider burrows in lowly impacted plots because they have limited presence of pedestrians [24]. This is confirmed during field work where bigger holes were seen in undisturbed areas. The holes are wider in lowly impacted plot, which is closer to the river, and farther away from human presence (Table 1) as a result they have no problem about attacks by reptile and ro- 
dents that scout for food in waste dump. In contrast, the highly impacted plot had the smallest width because of the fear of pedestrians who step on their holes, or trample and crush them to death, which was often observed along the foot path. However, the case for the Atlantic ghost crab (Ocypode quadrata) is different because they are mainly killed by vehicles rather than by foot on sandy beaches [25]. In contrast, the highly impacted plot has the longest burrow length to provide a safety net for the crabs when confronted by predators or the presence of humans who capture them, and use them as baits for fishing. This is in line with the study by Gul and Griffen [26] who found out that crabs in highly disturbed area confine themselves to edges of beaches. They further revealed that ghost crabs altered their burrow morphology, by creating deeper, steeper and smaller burrows under human impacts. The lowly impacted plot also has the shortest length because they have little or no external disturbances. However, the surface area, which was calculated from a combination of half of the width $(r)$ and full length $(h)$ of the burrows, provided a hidden truth about the morphology of the fiddler crab burrow (Figure 2). This is because the result revealed that less disturbed area (i.e. lowly impacted plot), had the largest surface area, which means in a less disturbed environment male fiddler crabs exhibited their constructing skills to the fullest by building bigger and more comfortable burrows that can accommodate their female counterpart during mating. On the other hand, human presence limit their ability to build bigger and better burrows because in a disturbed environment what matters most is a place to hide and not the nature or size of the burrow. A second reason why crabs built bigger holes in the less disturbed plot is because the soil is less consolidated as a result of lack of human presence whereas the soil in the more disturbed areas had been compacted because of constant trampling by pedestrians along the footpath (Table $1)$.

The number of burrows per plot also determined the level of human disturbance in the study area, which may also influence crab population [27]. This is because more burrows were found in the lowly impacted plot $(n=55)$ than in the medium $(n=30)$ and highly $(n=23)$ impacted plots because more crabs had the confidence in constructing their burrows in areas without human disturbance than areas that are disturbed, as human presence disrupt their building activities. Moreover, lowly impacted plot had more burrows because the crabs take lesser time to build their holes because of the soft nature of the soil. In contrast, the soil in the highly impacted plot is hard and therefore, the crabs take longer time to bore holes through it. Apart from human presence, temperature can also influence species abundance and distribution [28].

Although, there was no significant difference in the chemical composition of the burrow soils, the result however, shows that the highly impacted plot had more heavy metals (i.e. $\mathrm{Cd}, \mathrm{Pb}$ and $\mathrm{Zn}$ ) as compared to other plots due to the presence of human activity. The higher heavy metal concentration may also be caused by diesel leakage from swamp buggies and bulldozers used to clear the mangrove forest [29]. Again, heavy metals can seep into the soil from decom- 
posed electronic parts thrown into the waste dump near the foot path [30]. Cadmium and Lead, two poisonous chemicals, were more in highly impacted soil, which is another additional factor that would have prevented the crabs from constructing bigger and more comfortable burrows. This is because in the process of constructing the burrows the crab practically put some soils in their mouth while salivating to soften the ground to help them bore holes faster. Pollutants in the soil are detrimental to the health of the crabs because it can affect the endocrine and reproductive function of the crabs [31], which may prevent them from building good burrows. However, Zinc concentration, which was higher in lowly impacted plot, was previously reported to be high in that location [32] and generally in the coastal areas [33]. Zinc is a major chemical product from coastal bed rock [34], and forms part of the nutritional needs of organisms that inhabit land or water, but in high amount it can be detrimental to the health of organisms.

\section{Conclusion}

This study had shown that fiddler crabs (Uca tangeri) can serve as bio-monitoring agents in determining the level of human disturbance in coastal environment. This is because their ability to construct big burrows is highly influenced by human presence. The construction of burrows by crabs is to ensure their survival in tough coastal environment, where they face natural stress daily such as fluctuating and irregular tidal surge that submerges and fills their burrows with water caused by unpredictable weather condition due global warming. The crabs also face predators such as rodents and snakes that chase them out and colonize their burrows. Therefore, an additional impact by humans will push them to the brink of extinction if nothing is done to save their habitat. Fiddler crabs (U. tangeri) play a key role in recycling of nutrients and sub-surface oxygen through their burrowing behavior. As a way of conserving the crabs safe areas can be created for them to forage and provide their ecosystem services. Future studies will consider the impact of other predators such as reptiles, rodents and invasive species on crab burrow morphology.

\section{Acknowledgements}

I thank my research team comprising of Mr. Chimezie Brown and my 2019 undergraduate students for assistance in sample collection.

\section{Conflicts of Interest}

The author declares no conflicts of interest regarding the publication of this paper.

\section{References}

[1] Banerjee, K., Sahoo, N.R. and Khemundu, G.R. (2020) Geoengineering Structures of Crabs and Their Role in Nutrient Cycling in Mangrove Ecosystem of Mahanadi 
Delta, Odisha, India. In: Environmental Processes and Management, Springer, Cham, 155-200. https://doi.org/10.1007/978-3-030-38152-3 10

[2] Otero, X.L., Araújo, J., Barcellos, D., Queiroz, H.M., Romero, D.J., Nóbrega, G.N., Ferreira, T.O., et al. (2020) Crab Bioturbation and Seasonality Control Nitrous Oxide Emissions in Semiarid Mangrove Forests (Ceará, Brazil). Applied Sciences, 10, 2215. https://doi.org/10.3390/app10072215

[3] Horn, D., Miller, M., Anderson, S. and Steele, C. (2019) Microplastics Are Ubiquitous on California Beaches and Enter the Coastal Food Web through Consumption by Pacific Mole Crabs. Marine Pollution Bulletin, 139, 231-237.

https://doi.org/10.1016/j.marpolbul.2018.12.039

[4] Koga, T., Goshima, S., Murai, M. and Poovachiranon, S. (1995) Predation and Cannibalism in the Male Fiddler Crab Ucatetragonon. Journal of Ethology, 13, 181-183. https://doi.org/10.1007/BF02350110

[5] Milner, R.C., Detto, T., Jennions, M.D. and Backwell, P.Y. (2010) Hunting and Predation in a Fiddler Crab. Journal of Ethology, 28, 171-173. https://doi.org/10.1007/s10164-009-0156-x

[6] Takeda, S., Poovachiranon, S. and Murai, M. (2004) Adaptations for Feeding on Rock Surfaces and Sandy Sediment by the Fiddler Crabs (Brachyura: Ocypodidae) Ucatetragonon (Herbst, 1790) and Ucavocans (Linnaeus, 1758). Hydrobiologia, 528, 87-97. https://doi.org/10.1007/s10750-004-1874-2

[7] Pardo, J.C., Stefanelli-Silva, G., Christy, J.H. and Costa, T.M. (2020) Fiddler Crabs and Their Above-Ground Sedimentary Structures: A Review. Journal of Ethology, 38, 137-154. https://doi.org/10.1007/s10164-020-00647-1

[8] Mokhlesi, A., Kamrani, E., Backwell, P. and Sajjadi, M. (2011) Sexual Differences in Foraging Behaviour of Fiddler Crab, Ucasindensis (Decapoda: Ocypodidae). Journal of the Persian Gulf, 2, 37-44.

[9] Kristensen, E. (2008) Mangrove Crabs as Ecosystem Engineers; with Emphasis on Sediment Processes. Journal of Sea Research, 59, 30-43.

https://doi.org/10.1016/j.seares.2007.05.004

[10] Zeil, J. (1998) Homing in Fiddler Crabs (Uca Lactea Annulipes and Uca Vomeris: Ocypodidae). Journal of Comparative Physiology A, 183, 367-377. https://doi.org/10.1007/s003590050263

[11] France, R. (1998) Estimating the Assimilation of Mangrove Detritus by Fiddler Crabs in Laguna Joyuda, Puerto Rico, Using Dual Stable Isotopes. Journal of Tropical Ecology, 14, 413-425. https://doi.org/10.1017/S0266467498000315

[12] Liu, M., Zhang, H., Lin, G., Lin, H. and Tang, D. (2018) Zonation and Directional Dynamics of Mangrove Forests Derived from Time-Series Satellite Imagery in Mai Po, Hong Kong. Sustainability, 10, 1913. https://doi.org/10.3390/su10061913

[13] Sarker, S., Masud-Ul-Alam, M., Hossain, M.S., Rahman Chowdhury, S. and Sharifuzzaman, S. (2020) A Review of Bioturbation and Sediment Organic Geochemistry in Mangroves. Geological Journal, 1-12. https://doi.org/10.1002/gj.3808

[14] Hanim, N., Aditya, I., Rini, M., Farajallah, A. and Wardiatno, Y. (2020) Newly Distribution Record of Four Marine Crabs (Decapoda: Brachyura) Collected from Seribu Island-Jakarta, Indonesia. IOP Conference Series: Earth and Environmental Science, 457, Article ID: 012022. https://doi.org/10.1088/1755-1315/457/1/012022

[15] Numbere, A.O. (2020) Total Hydrocarbon and Heavy Metal Concentrations in Body Parts of Fiddler Crab (Uca tangeri) (Ocipodidae) in the Niger Delta, Nigeria. International Journal of Marine Science, 10, 1-9.

https://doi.org/10.5376/ijms.2020.10.0001 
[16] Kobayashi, S. and Archdale, M.V. (2020) Mating Behaviour of the Leucosiid Crab Pyrhila pisum (De Haan, 1841). Journal of the Marine Biological Association of the United Kingdom, 100, 103-113. https://doi.org/10.1017/S0025315419001140

[17] APHA (1995) 1985 American Public Health Association (APHA) Standard Method for the Examination of Water and Waste Water. 19th Edition, Washington DC.

[18] Aigberua, A. and Tarawou, T. (2018) Speciation and Mobility of Selected Heavy Metals in Sediments of the Nun River System, Bayelsa State, Nigeria. Environmental and Toxicology Studies Journal, 2, 1.

[19] Aigberua, A. and Numbere, A.O. (2019) Assessment of Dumpsite Soil in Mangrove Forest at Eagle Island, Nigeria: It's Effect on Potential Bioavailability of Heavy Metals in the Environment. Journal of Petroleum \& Environmental Biotechnology, 10, 1-9. https://doi.org/10.35248/2157-7463.19.10.390

[20] Logan, M. (2010) Biostatistical Design and Analysis Using R: A Practical Guide. John Wiley and Sons, Hoboken. https://doi.org/10.1002/9781444319620

[21] Quinn, G.P. and Keough, K.J. (2002) Experimental Design and Data Analysis for Biologists. Cambridge University Press, London.

https://doi.org/10.1017/CBO9780511806384

[22] R Development Core Team (2013) R: A Language and Environment for Statistical Computing. R Foundation for Statistical Computing, Vienna.

[23] Sen, S. and Homechaudhuri, S. (2018) Comparative Burrow Architectures of Resident Fiddler Crabs (Ocypodidae) in Indian Sundarban Mangroves to Assess Their Suitability as Bioturbating Agents. Proceedings of the Zoological Society, 71, 17-24. https://doi.org/10.1007/s12595-016-0178-7

[24] Barakali, D., Snaddon, J.L. and Snape, R.T. (2020) Revisiting the Population of the Ghost Crab, Ocypode Cursor, on the Sandy Beaches of Northern Cyprus after Two Decades: Are There Causes for Concern? Zoology in the Middle East, 66, 1-8. https://doi.org/10.1080/09397140.2020.1729556

[25] Costa, L.L., Secco, H., Arueira, V.F. and Zalmon, I.R. (2020) Mortality of the Atlantic Ghost Crab Ocypode quadrata (Fabricius, 1787) Due to Vehicle Traffic on Sandy Beaches: A Road Ecology Approach. Journal of Environmental Management, 260, Article ID: 110168. https://doi.org/10.1016/j.jenvman.2020.110168

[26] Gül, M.R. and Griffen, B.D (2018) Impacts of Human Disturbance on Ghost Crab Burrow Morphology and Distribution on Sandy Shores. PLOS ONE, 13, e0209977. https://doi.org/10.1371/journal.pone.0209977

[27] Steibl, S. (2020) Terrestrial Hermit Crab Populations in the Maldives: Ecology, Distribution and Anthropogenic Impact. Springer Fachmedien, Wiesbaden. https://doi.org/10.1007/978-3-658-29541-7

[28] Tiralongo, F., Messina, G., Marino, S., Bellomo, S., Vanadia, A., Borzì, L., Lombardo, B.M., et al. (2020) Abundance, Distribution and Ecology of the Tufted Ghost Crab Ocypode cursor (Linnaeus, 1758)(Crustacea: Ocypodidae) from a Recently Colonized Urban Sandy Beach, and New Records from Sicily (Central Mediterranean Sea). Journal of Sea Research, 156, Article ID: 101832.

https://doi.org/10.1016/j.seares.2019.101832

[29] USEPA (1996) Report: Recent Developments for in Situ Treatment of Metals Contaminated Soils, U.S. Environmental Protection Agency, Office of Solid Waste and Emergency Response.

[30] Numbere, A.O. (2019) Municipal Solid Waste Disposal in Mangrove Forest: Environmental Implication and Management Strategies in the Niger Delta, Nigeria. In: 
Municipal Solid Waste Management, IntechOpen, London, 1-14.

[31] Park, K., Jo, H., Kim, D.K. and Kwak, I.S. (2019) Environmental Pollutants Impair Transcriptional Regulation of the Vitellogenin Gene in the Burrowing Mud Crab (Macrophthalmus Japonicus). Applied Sciences, 9, 1401.

https://doi.org/10.3390/app9071401

[32] Numbere, A.O. (2019) Bioaccumulation of Total Hydrocarbon and Heavy Metals in Body Parts of the West African Red Mangrove Crab (Goniopsis pelii) in the Niger Delta, Nigeria. International Letters of Natural Sciences, 75, 1-12. https://doi.org/10.18052/www.scipress.com/ILNS.75.1

[33] Levy, D.B., Barbarick, K.A., Siemer, E.G. and Sommers, L.E. (1992) Distribution and Partitioning of Trace Metals in Contaminated Soils near Leadville, Colorado. Journal of Environmental Quality, 21, 185-195. https://doi.org/10.2134/jeq1992.00472425002100020006x

[34] Buekers, J. (2007) Fixation of Cadmium, Copper, Nickel and Zinc in Soil: Kinetics, Mechanisms and Its Effect on Metal Bioavailability. PhD Thesis, Katholieke Universiteit Lueven, Dissertationes De Agricultura. 